\title{
OPTIMALISASI PEMANFAATAN Clitoria Ternatea SEBAGAI PAKAN SUPLEMEN PEDET SAPI BALI
}

\author{
L.R. Deze ${ }^{1}$, I.G.N. Jelantik ${ }^{2}$, T.T. Nikolaus ${ }^{3}$ \\ ${ }^{1,2,3}$ Program Studi Peternakan, Program Pasca Sarjana, \\ Universitas Nusa Cendana \\ Korespondensi: Jl. Adisucipto, Kupang, NTT 85001 \\ Email: lellydeze@gmail.com
}

\begin{abstract}
Abstrak
Penelitian ini bertujuan untuk mengetahui pemanfaatan C. ternatea yang dioptimalisasikan dengan tepung ubi kayu yang dapat menurunkan angka kematian serta meningkatkan pertambahan berat badan pedet sapi Bali. Penelitian ini dibagi dalam dua tahap penelitian. Pada penelitian tahap I dilakukan pengujian in vitro untuk mengetahui level ideal kombinasi antara $C$. ternatea dan tepung umbi ubi kayu dengan perlakuan $\mathrm{R} 0=100 \%$ C. ternatea $; \mathrm{R} 1=90 \%$ C. ternatea + $10 \%$ Ubikayu; R2 $=80 \%$ C. ternatea $+20 \%$ Ubikayu; R3 $=70 \% C$. ternatea $+30 \%$ Ubikayu; $44=60 \%$ C. ternatea $+40 \%$ Ubikayu. Hasil penelitian ini menunjukan bahwa level kombinasi terbaik diperoleh pada kombinasi $60 \%$ C. ternatea $+40 \%$ ubikayu dengan nilai kecernaan bahan kering dan bahan organik sebesar $68,07 \%$ dan $68,59 \%$. Berdasarkan hasil penitian I ini maka dilakukan penelitian tahap II untuk mengetahui respon biologis dari pedet sapi Bali. Sebanyak 80 ekor pedet sapi Bali digunakan dalam penelitian tahap II ini. Parameter yang diamati dalam penelitian ini adalah pertambahan berat badan, ukuran linier tubuh dan angka kematian pedet sapi Bali. Hasil penelitian tahap II ini menunjukan bahwa suplementasi $C$. ternatea yang dikombinasikan dengan ubi kayu secara nyata meningkatkan pertambahan berat badan, perubahan ukuran linier tubuh dan menekan mortalitas pedet sapi Bali sama nilainya untuk anak sapi yang mengkonsumsi pakan konsentrat.
\end{abstract}

Kata Kunci : C. ternatea, in vitro, pertambahan berat badan, angka kematian, ukuran linear tubuh, pedet sapi Bali 


\title{
OPTIMILIZATION USAGE OF CLITORIA TERNATEA AS SUPPLEMENT FOODS FOR BALI CALVES
}

\begin{abstract}
This research aims to know the usage of $C$. ternatea, optimalized with tapioca that can reduce the mortality and increase the weight of Bali calves. This research is divided into two phases. In the first phase, in vitro test is done to know the ideal combination level between $C$. ternatea and tapioca, with $\mathrm{R} 0=100 \%$ C. ternatea; $\mathrm{R} 1=90 \%$ C.ternatea $+10 \%$ tapioca; R2 $=80 \%$ C.ternatea $+20 \%$ tapioca; R3 $=70 \%$ C.ternatea $+30 \%$ tapioca; $\mathrm{R} 4=60 \%$ C. ternatea $+40 \%$ tapioca. The result of research shows that R3, that is $60 \%$ C. ternatea and $40 \%$ tapioca is the best combination level with $67.44 \%$ digestibility for dry matters and $67,87 \%$ for organics. Based on the results of the first study the second one is done to know the biological response of Bali calves. There were 79 Bali calves taken as sample for this research. Parameters for this second research are body weight, linear body size and mortality of Bali calves. The result of this second research shows that $C$. ternatea supplements combined with tapioca clearly can increase the body weight and linear body size and reduce the mortality of Bali calves equals to calves that are given concentrate.
\end{abstract}

Key words : C. ternatea, in vitro, body weight, mortality, linear body size, Bali calves

\section{PENDAHULUAN}

Pakan merupakan salah satu faktor utama yang menentukan tingginya produksi peternakan ruminansia di musim kemarau dengan rendahnya curah hujan. Pada musim ini ternak ruminansia mengalami penurunan berat badan yang dapat menyebabkan tingginya angka kematian karena rendahnya ketersediaan pakan hijauan. Hal inilah yang mengakibatkan peurunan berat badan yang dapat menyebabkan tingginya angka kematian ternak sapi di Nusa Tenggara Timur dan berdampak terhadap penurunan jumlah produktivitas sapi dari daerah ini. Kelahiran pedet biasanya terjadi pada musim kemarau, oleh karena tidak didukung dengan ketersediaan pakan menyebabkan tingginya kematian pedet (Jelantik et al., 2008). Kekurangan pakan hijuan di 
musim kemarau mengakibatkan rendahnya produksi air susu induk sapi untuk pertumbuhan dan perkembangan anak sapi sehingga menyebabkan tingginya angka kematian pada anak sapi (Bamualim dan Wirdahayati, 2005).

Pertumbuhan dan kualitas bakalan dapat ditingkatkan dengan menggunakan teknologi pakan suplemen pedet dan teknologi ini juga dapat menekan angka kematian dan meningkatkan kaualitas bakalan. Tetapi hingga saat ini adopsi teknologi pakan suplemen pedet oleh masyarakat masih relatif rendah. Faktor-faktor seperti keterbatasan ketersediaan dan harga pakan suplemen pedet tingkat peternak dan pedet yang dipisahkan dari induk yang dianggap sebagai teknik yang sangat baik oleh peternak dan secara ekonomis sangat feasible $(B / C$ ratio 6,47) Sogen et al., 2010; Copland et al., 2010) merupakan salah satu penyebab rendahnya laju adopsi (Jermias et al., 2010). Penelitian yang dilakukan oleh Jelantik $d k k$., (2014) untuk meningkatkan adoptabilitas teknologi pakan suplemen pedet dengan menggantikan sebagian pakan suplemen konsentrat dan leguminosa herbal seperti kacang nasi, siratro dan Clitoria ternatea yang dapat dihasilkan sendiri oleh peternak tanpa harus membeli dari pasaran. Hasil penelitian menunjukkan bahwa pertambahan berat badan yang dihasilkan dari penggantian $60 \%$ pakan suplemen sama nilainya dengan pakan suplemen konsentrat. $C$. ternatea paling prospektif digunakan sebagai bahan dasar pakan suplemen pedet karena tingginya produksi dan kualitas hijauan dibandingkan dengan leguminosa lainnya (Jelantik, 2015).

Tanaman C. ternatea mengandung protein kasar berkisar 21-29\%, energi kasar 18,6 MJ/kg, kecernaan bahan organik 69,7\%, kecernaan energi 66,6\% dan energi termetabolis pada ruminan 12,4 MJ/kg. Pada bijinya kandungan protein kasar (25-38\%), lemak kasar (10\%) dan gula $(5 \%)$, dan ternak ruminansia dapat memperoleh sumber protein dan energi dari leguminosa jenis ini. Pertumbuhan ternak ruminansia tidak memberikan respon negatif apabila ternak diberikan leguminosa ini baik berupa hijuan segar maupun berupa hay. Untuk mengoptimalkan pemanfaatan C. ternatea diperlukan tambahan pakan sumber energi. Ubi kayu merupakan pakan sumber energi yang murah dan dapat dihasilkan sendiri oleh peternak. Kandungan nutrisi protein kasar ubi kayu 4,12\%, serat kasar 27,20\%, lemak kasar 0,70\%, bahan kering 92,60 \% dan kadar abu 4,05 \% (Mirwandhono dkk., 2006). 
Dengan demikian dibutuhkan penelitian yang mengkaji penggunaan $C$. ternatea yang dikombinasikan dengan ubi kayu sebagai pakan suplemen pedet sehingga teknologi pakan suplemen pedet dapat lebih diadopsi oleh peternak.

\section{METODE}

Penelitian ini menggunakan dua tahapan penelitian:

1. Pada tahap ini akan dilakukan pengujian secara in vitro level pemberian Clitoria dan ubi kayu secara invitro dengan menggunakan rancangan acak lengkap 5 perlakuan dan 4 ulangan. Perlakuan yang diuji: $(\mathrm{R} 0=100 \%$ C. ternatea $) ;(\mathrm{R} 1=$ $90 \%$ C. ternatea $+10 \%$ ubi kayu); $(\mathrm{R} 2=80 \%$ C. ternatea + $20 \%$ ubi kayu $) ;(\mathrm{R} 3=70 \%$ C. ternatea $+30 \%$ ubi kayu $) ;(\mathrm{R} 4=$ $60 \%$ C. ternatea $+40 \%$ ubi kayu). Pengukuran kecernaan in vitro dilakukan dengan teknik dua tahap berdasarkan petunjuk Tilley dan Terry (1963). Variabel yang diamati pada penelitian ini adalah kecernaan bahan kering dan bahan organik secara in vitro. Data yang diperoleh dianalisis berdasarkan sidik ragam menggunakan rancangan acak lengkap (RAL) dan dianalisis menggunakan SPSS 17.

2. Pada tahap ini akan dilakukan pengujian secara in vivo level pemberian Clitoria dan ubi kayu pada ternak sapi bali sapihan pada peternakan rakyat. Penelitian ini dilaksanakan di Desa Oefafi Kecamatan Kupang Timur dengan menggunakan 79 ekor pedet dengan berat badan $30-50 \mathrm{~kg}$. Penelitian ini menggunakan rancangan acak lengkap 4 perlakuan dan 20 ulangan sehingga jumlah ternak sapi yang digunakan berjumlah 80 ekor pedet sapi Bali yang sedang menyusui. Perlakuan yang dicobakan adalah (Kontrol $=$ Kontrol dimana pedet mengkonsumsi rumput alam); (Konsentrat = Pedet yang sedang menyusui diberikan suplemen konsentrat 2\% BB); (C.ternatea $=$ Pedet yang sedang menyusui diberikan pakan tambahan berupa hay $C$. ternatea $2 \% \mathrm{BB}) ;(\mathrm{Ct}+\mathrm{Ubi}$ kayu $=$ Pedet yang sedang menyusu diberikan pakan tambahan berupa kombinasi C. ternatea dan ubikayu $2 \%$ BB yang merupakan kombinasi terbaik hasil penelitian tahap pertama). Parameter yang diamati pada penelitian ini adalah moratalitas, pertambahan berat badan dan ukuran linear tubuh sapi bali sapihan. Semua data yang 
diperoleh dianalisis dengan analisis sidik ragam (analysis of variance) menggunakan software SPSS 17.

\section{HASIL DAN PEMBAHASAN \\ Hasil}

Penambahan ubikayu dalam ransum berbasis Clitoria ternatea merupakan upaya untuk meningkatkan nilai nutrisi ransum. Estimasi peningkatan suplai nutrisi ternak dalam penelitian ini diukur dengan pengukuran kecernaan secara in vitro. Hasil dari penelitian ini menunjukkan bahwa kecernaan bahan kering in vitro bervariasi antara $61,81-68,07 \%$ dengan rata-rata $65,51 \%$ dan kecernaan bahan organiknya mencapai $63,32-68,59 \%$. Secara umum nilai kecernaan tersebut cukup tinggi, yang menunjukan bahwa ransum berbasis Clitoria ternatea mempunyai nilai nutrisi yang tinggi bagi ternak ruminansia. Sebagai contoh, hasil ini lebih tinggi dengan kecernaan bahan kering $(37,85-49,25)$ dan bahan organik $(51,13-68,53 \%)$ silase rumput kumpai yang disuplementasi dengan legum turi mini (Riswandi, 2014).

Tabel 1. Pengaruh Suplementasi Terhadap Rataan Pertambahan Berat Badan, dan Ukuran Linear Tubuh Pedet.

\begin{tabular}{|c|c|c|c|c|c|c|}
\hline \multirow[b]{2}{*}{ Parameter } & \multicolumn{4}{|c|}{ Perlakuan } & \multirow[b]{2}{*}{ SEM } & \multirow[b]{2}{*}{$\mathrm{P}$} \\
\hline & Kontrol & C. ternatea & $\begin{array}{l}\mathrm{Ct}+\text { ubi } \\
\text { kayu }\end{array}$ & Konsentrat & & \\
\hline $\begin{array}{l}\text { PBBh } \\
\text { (kg/ekor/hr) }\end{array}$ & $0.02^{\mathrm{a}}$ & $0.06^{\mathrm{b}}$ & $0.08^{\mathrm{b}}$ & $0.10^{\mathrm{b}}$ & 0.01 & $<0.01$ \\
\hline PPB_(cm/hr) & 0.03 & 0.04 & 0.04 & 0.05 & 0.00 & 0.29 \\
\hline PTP_(cm/hr) & $0.02^{\mathrm{a}}$ & $0.04^{\mathrm{b}}$ & $0.04^{\mathrm{b}}$ & $0.05^{b}$ & 0.00 & 0.02 \\
\hline PLD_(cm/hr) & -0.01 & 0.02 & 0.04 & 0.04 & 0.02 & 0.81 \\
\hline
\end{tabular}

Keterangan : Superskrip huruf kecil yang berbeda pada baris yang sama menunjukan perbedaan yang nyata $(\mathrm{P}<0,05)$

Tepung ubi kayu merupakan bahan pakan yang mudah dicerna terlebih lagi adanya peningkatan persentase pemberian tepung ubi kayu dalam ransum perlakuan. Ternak ruiminansia pencernaanya terjadi secara mekanik atau terjadi dalam mulut dan secara fermentatif, semuanya tergantung pada ransum serta kandungan nutirisinya 
sehingga memerlukan unsur $\mathrm{N}$ dan kerangka atom $\mathrm{C}$ dalam pertumbuhannya (Jouany dan Ushida, 1999). Dari hasil ini diuji lanjut secara in vivo pada pedet sapi Bali untuk melihat pengaruh pemberian suplemen pakan $C$. ternatea yang dikombinasikan dengan ubi kayu yang dapat menurunkan mortalitas serta meningkatkan PBB dan pengaruh suplementasi terhadap perubahan ukuran linear tubuh.

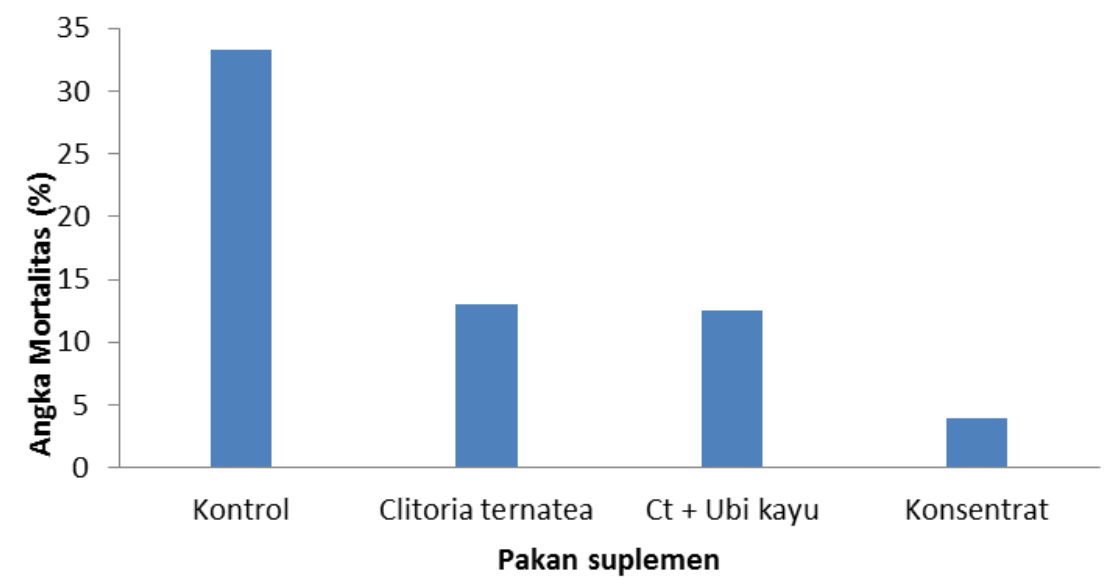

Gambar 1. Persentase tingkat kematian anak Sapi Bali yang mendapatkan pakan suplemen dan tanpa pakan suplemen

\section{Pembahasan}

Kematian pedet yang sangat tinggi dan rendahnya laju pertumbuhan pedet sapi Bali merupakan penyebab utama rendahnya produksi dan kualitas bakalan yang dihasilkan dari sistem peternakan ekstensif di NTT. Mullik dan Jelantik (2010) menyatakan bahwa teknologi suplementasi pakan suplemen pedet yang telah dikembangkan selama ini dapat menekan angka kematian dan meningkatkan kualitas bakalan.Akan tetapi adoptabilitas teknologi pakan suplemen pedet oleh petani peternak dirasakan masih relatif rendah. Upaya dalam penyerapan teknologi pakan suplemen pedet telah dilakukan oleh Jelantik $d k k$. (2015) dengan menggantikan sebagian pakan suplemen konsentrat dengan leguminosa herba seperti kacang nasi, siratro dan $C$. ternatea yang dapat dihasilkan sendiri oleh peternak tanpa harus membeli dari pasaran. 
Dari hasil penelitian ini Gambar 1. juga terlihat jelas bahwa terdapat perbedaan yang mencolok antara mortalitas pedet pada dua strategi yakni tanpa pakan suplemen dan yang diberikan pakan suplemen. Pemberian pakan suplemen mampu menurunkan angka kematian pedet sapi Bali 33,33\% menjadi 9,85\%. Hasil penelitian ini membuktikan bahwa dengan cara sederhana dapat menurunkan tingkat mortalitas anak sapi di NTT. Dengan demikian, memberikan sedikit pakan suplemen ketika pedet kembali ke kandang bersama induknya setelah digembalakan dan memberikan sedikit hay C. ternatea serta kombinasi hay $C$. ternatea dan tepung ubi kayu, maka kematian pedet dapat dihindarkan. Jika strategi ini diadopsi oleh sebagian besar peternak di NTT maka strategi ini akan berdampak sangat besar terhadap produktivitas sapi Bali di NTT.

Berat badan pedet sapi Bali meningkat sebesar 33,33\% pada musim kemarau. Data dalam Tabel 1 memperlihatkan penggunaan pakan suplemen pedet berbasis $C$. ternatea ditambahkan tepung ubikayu tidak berbeda dengan suplemen konsentrat. Hal ini memberi gambaran bahwa strategi suplementasi menggunakan legum $C$. ternatea ditambahkan tepung ubikayu memberikan potensi yang sama dan dapat digunakan sebagai pengganti pakan suplemen berbasis konsentrat dalam meningkatkan PBB pedet. Fenomena ini mendukung apa yang laporkan Jelantik $d k k$., (2015c) dalam mempertimbangankan adopsi pakan suplemen pedet (konsentrat) diantaranya keterbatasan ketersediaan dan harga pakan suplemen pedet yangdigunakan peternak serta pedet yang dipisahkan dari induk yang dianggap sebagai teknik yang sangat baik oleh peternak dan secara ekonomis sangat feasible (B/C ratio 6,47) Sogen et al., 2010; Copland et al., 2010. Dengan demikian dibutuhkan upaya untuk memecahkan permasalahan tersebut sehingga laju adopsi teknologi pakan suplemen pedet dapat ditingkatkan yang salah satu alternatifnya adalah penggunan leguminosa herbal sebagai pakan suplemen diantaranya $C$. ternatea yang disubtitusi pakan sumber energi (tepung ubi kayu) dengan perolehan $\mathrm{PBBH}$ pedet sapi Bali sebesar 82,52 g dengan selisih 13,34 $\mathrm{g}$ PBBh dari pakan suplemen konsentrat.

Pertambahan tinggi pundak pada ternak yang mendapat suplemen dan tanpa suplemen adalah $0,04 \mathrm{~cm} /$ ekor/hari dan $0,02 \mathrm{~cm} / \mathrm{ekor} / \mathrm{hari}$. Dengan demikian, terlihat adanya perbedaan tinggi pundak rata rata dari pedet yang mendapat pakan suplemen dan tanpa suplemen. 
Perbedaan ini disebabkan oleh adanya pemberian pakan suplemen pada pedet untuk menutupi stres nutrisi di musim kemarau. Dengan demikian terjadi perubahan kondisi tubuh pedet akibat dari kecukupan nutrisi yang berdampak deposisi protein menjadi otot dan lemak subkutan.

Lingkar dada merupakan ukuran linear tubuh yang dipengaruhi oleh ukuran kerangka dan juga oleh kondisi tubuh yakni tebal tipisnya jaringan otot dan lemak (Lay $d k k$., 2000). Pada saat ternak dalam kondisi gemuk, ukuran lingkar dadanya akan lebih besar, tetapi pada saat kondisinya menurun atau kurus, kemungkinan karena penyakit maka ukuran lingkar dadanya akan menyusut.

\section{SIMPULAN}

Uji kencernaan secara in vitro didapatkan pada kombinasi penggunaan pakan $60 \%$ C. ternatea dan $40 \%$ tepung umbi ubi kayu merupakan level yang terbaik. Pada uji in vivo dimana pemberian pakan suplemen berbasis hay C. ternatea yang dikombinasikan dengan ubi kayu pada malam harinya selepas penggembalaan mampu menurunkan angka kematian (mortalitas) pedet dari 33,33\% menjadi 9,85\% memiliki nilai setara dengan pedet sapi yang mendapatkan pakan suplemen konsentrat, setara dengan pedet sapi yang mendapatkan pakan suplemen konsentrat. Pemberian suplemen kombinasi hay $C$. ternatea dan tepung ubi kayu pada pedet secara nyata meningkatkan PBB dan pertambahan ukuran linear tubuh serta dapat menekan angka kematian anak sapi Bali sama nilanya dengan anak sapi Bali yang diberikan konsntrat.

\section{UCAPAN TERIMA KASIH}

Disampaikan kepada semua pihak yang dengan caranya masingmasing telah membantu penulis untuk menyelesaikan penelitian ini.

\section{DAFTAR PUSTAKA}

Bamualim, A. Dan Wirdahayati R.B. (2005). Potensi Padang Rumput Alam Di Nusa Tenggara Timur Untuk Produksi Sapi Potong. Pros. Seminar Nasional Pengembangan Usaha Peternakan Berdaya Saing di Lahan Kering. Kerjasama Fakultas Peternakan UGM dengan Pustlitbang Peternakan. Lustrum VII Fakultas 
Peternakan Universitas Gajah Mada. Fakultas Peternakan UGM, Yogyakarta. Hlm. 49-56

Copland, RS., IGN Jelantik, and ML Mullik. (2011). Evaluating Strategies to Improve Calf Survival in West Timor Vilages. ACIAR GPO Box 1571, Canberra ACT 2601 Australia.

Jelantik, I. G. N., M. L.Mullik, C. Leo-Penu, J. Jeremias and R. Copland. (2008). Improving Calf Survival and Performance by Supplementation in Bali Cattle. Autralian Journal Of Experimental Agriculture. Volume 48 Issue 6-7 pp. 950-953

Jelantik, I. G. N. (2015). Pemanfaatan Pakan Suplemen Pedet Berbasis Leguminosa Herbal Untuk Meningkatkan Populasi Sapi Bali. Dalam : Proseding Seminar Nasional "Percepatan Peningkatan Populasi Sapi Bali Untuk Menunjang Suplai Kebutuhan Daging Sapi Nasional" Kupang 28 November 2015.

Jelantik IGN, Nikolaus TT, Leo-Penu C, Jeremias J. (2015). Herbage Production and Nutritive Value Of Some Forage Legumes As Calf Supllement. Proceeding 3rd Internatinal Seminar On Animal Industry. 141-144.

Jeremias Ja, DR Tulle, C Leo-Penu, and IGN Jelantik. (2010). Tingkat Pendapatan Peternak Pada Penggemukan Sapi Bali Dengan Sistem Bagi Hasil di Kabupaten Kupang. Partner. Vol 17 (1) : 43-50.

Jouany, J. P., and K. Ushida, (1999). The Role Of Protozoa in Feed Digestion. Review. African Journal of Animal Science 12 : 113 128.

Mirwandono, E., I. Bachari dan D. Situmorang. (2006). Uji Nilai Nutrisi Kulit Ubi Kayu Yang Difermentasi Dengan Aspergillus Niger (Nutient Value Test Of Cassava Tuber Skin Fermented By Aspergillus Niger). Jurnal Agribisnis Peternakan. 2 (3) : 91-95.

Mullik, ML, dan IGN Jelantik. (2010). Strategi Peningkatan Produktivitas Sapi Bali Pada Sistem Pemeliharaan Ekstensi di Daerah Lahan Kering: Pengalaman Nusa Tenggara Timur. Dalam : Proseding Seminar Nasional Pengembangan sapi Bali 
Berkelanjutan dalam Sistim Peternakan Rakyat. Mataram, 28 Oktober 2009.

Sogen, J. G. A. A. Nalle, F. L. Benu, and R. S. Copland. (2010). The Economic Benefits of Improved Calf Survival and Growt Trough Supplementing Bali Cattle Calves (BosSondaicus In West Timor Villages, Indonesia. Animal Production in Australia. Vol. 28:13. 